Decoding Gender 



\title{
Decoding Gender
}

\section{Law and Practice in Contemporary Mexico}

\author{
EDITED BY \\ HELGA BAITENMANN \\ VICTORIA CHENAUT \\ ANN VARLEY
}

FOREWORD BY

MAXINE MOLYNEUX 


\section{LIBRARY OF CONGRESS CATALOGING-IN-PUBLICATION DATA}

Decoding gender : law and practice in contemporary Mexico / edited by Helga Baitenmann, Victoria Chenaut, and Ann Varley.

p. $\quad \mathrm{cm}$.

Includes bibliographical references and index.

ISBN-13: 978-0-8135-4050-4 (hardcover : alk. paper)

ISBN-I3: 978-0-8I35-405I-I (pbk. : alk. paper)

I. Women-Legal status, laws, etc.-Mexico. 2. Sex and law-Mexico. 3. Indians of Mexico-Legal status, laws, etc.-Mexico. I. Baitenmann, Helga. II. Chenaut, Victoria. III. Varley, Ann

KGF462.W62D43 2007

346.720I'34-dc22

2006031255

A British Cataloging-in-Publication record for this book is available from the British Library.

This collection copyright (C) 2007 by Rutgers, The State University

Individual chapters copyright $\odot 2007$ in the names of their authors

All rights reserved

No part of this book may be reproduced or utilized in any form or by any means, electronic or mechanical, or by any information storage and retrieval system, without written permission from the publisher. Please contact Rutgers University Press, 100 Joyce Kilmer Avenue, Piscataway, NJ 08854-8099. The only exception to this prohibition is "fair use" as defined by U.S. copyright law.

Manufactured in the United States of America 